\title{
PENGARUH KEPEMIMPINAN, KOMPENSASI DAN PROMOSI JABATAN TERHADAP KINERJA KARYAWAN MELALUI KEPUASAN KERJA PADA PT. BANK JATIM, TbK CABANG PAMEKASAN
}

\author{
WAHYU MAULANA \\ UNIVERSITAS MADURA
}

\begin{abstract}
ABSTRAK
Perusahaan untuk menggapai tujuannya maka aspek sumber daya manusianya haruslah yang kompetitif. Kinerja SDM merupakan ujung tombak pencapaian tersebut. Oleh karenanya, perusahaan harus memberikan kepuasan kerja kepada karyawannya agar kinerjanya optimal dan maksimal. Berdasarkan permasalahan tersebut, penulis mengambil tema penelitian yaitu tentang "Pengaruh Kepemimpinan, Kompensasi dan Promosi Jabatan Terhadap Kinerja Karyawan Melalui Kepuasan Kerja Pada PT. Bank Jatim, Tbk Cabang Pamekasan". Tujuan penelitian untuk menganalisis pengaruh kepemimpinan, kompensasi dan promosi jabatan terhadap kepuasan kerja, serta menganalisis pengaruh kepemimpinan, kompensasi dan promosi jabatan terhadap kinerja karyawan secara langsung maupun tidak langsung melalui kepuasan kerja sebagai variabel intervening. Populasi serta sampel dalam penelitian ini merupakan karyawan secara keseluruhan berjumlah 88 responden. Metode analisa data menggunakan Partial Least Square (PLS). Hasil penelitiannya adalah kepemimpinan dan kompensasi berpengaruh terhadap kepuasan kerja karyawan sedangkan promosi jabatan tidak berpengaruh terhadap kepuasan kerja. Kepemimpinan dan promosi jabatan berpengaruh terhadap kinerja karyawan sedangkan kompensasi tidak berpengaruh terhadap kinerja karyawan dan kepuasan kerja berpengaruh terhadap kinerja karyawan. Kepuasan kerja merupakan variabel intervening diantara pengaruh kepemimpinan terhadap kinerja dan diantara pengaruh kompensasi terhadap kinerja karyawan sedangkan kepuasan kerja bukan merupakan variabel intervening diantara pengaruh promosi jabatan terhadap kinerja karyawan. Variabel promosi jabatan merupakan variabel dominan yang berpengaruh terhadap kinerja karyawan.
\end{abstract}

Kata kunci : Kepemimpinan, Kompensasi, Promosi Jabatan, Kepuasan Kerja dan Kinerja Karyawan 


\section{PENDAHULUAN LATAR BELAKANG}

Untuk menghadapi kompetisi persaingan dunia usaha yang semakin ketat, perusahaan diminta untuk melakukan optimalisasi berbagai aspek sumber daya perusahaan yang dimilikinya baik dari segi modal, mesin, sarana kerja, metode kerja, bahan baku, pemasaran ataupun SDMnya. Tidak sedikit jumlah para ilmuwan yang menilai faktor produksi sebuah perusahaan memiliki peranan yang sama penting keberadaannya. Faktor SDM harus diperhatikan dalam melaksanakan fungsi perusahaan karena dalam meraih keuntungan dan menjaga eksistensi, perusahaan wajib melakukan peningkatan kualitas pelayanan disamping menjaga konsistensi dalam proses produksinya. Permasalahan yang muncul ketika salah dalam mengelola SDM adalah penurunan kinerja karyawan.

Oleh sebab itu, pengelolaan SDM yang baik harus terus ditingkatkan guna menghasilkan kinerja perusahaan yang efektif efisien. Hal ini merupakan point keberhasilan bagi perusahaan yang sangat berpengaruh kepada integeritas, kinerja efektif efisien, transparansi para karyawannya. Karenanya, salah satu cara yang bisa diambil oleh sebuah perusahaan untuk mengatasi permasalahan tersebut adalah mengupayakan adanya kepuasan kerja para karyawannya sebagai motivasi atas totalitas dalam berkerja yang dapat menghasilkan keuntungan untuk perusahaan. Dengan kata lain, kinerja soerang karyawan terus meningkat seiring tercapainya sebuah kepuasan dalam bekerja. Ketika seorang karyawan merasakan kepuasan dalam melaksanakan pekerjaannya, sedikitnya secara psikologis akan mengerahkan seluruh usahanya semaksimal mungkin serta mengeluarkan kemampuannya secara maksimal dalam menyelesaikan tanggung jawabnya dengan penuh totalitas.

Setiap bentuk organisasi maupun perusahaan baik itu swasta maupun pemerintahan akan fokus pada orientasi pengembangan dalam jangka panjang yakni meningkatkan pendapatam usaha yang sekaligus berpengaruh pada kesejahteraan para karyawannya yang terus meningkat. Hal tersebut adalah salah satu indikator pencapaian pada tingkatan GCG (good corporate governance) sebuah perusahaan. Namun dalam pelaksanaannya masih banyak kendala yang dihadapi, diantaranya disebabkan oleh faktor ketidakpuasan karyawan dalam bekerja. Hal tersebut memiliki efek berkelanjutan pada kinerja secara individu atau kinerja perusahaan secara menyeluruh. Perusahaaan sangat dipengaruhi oleh kinerja para karyawannya, yang bilamana kinerjanya rendah maka terhambatlah pencapaian tujuan perusahaan tersebut. Kepuasan dalam bekerja bisa sangat mempengaruhi kinerja para karyawan, disebabkan kepuasan kerja mempunyai peranan penting dalam mengembangkan usaha perusahaan untuk peningkatan efisiensi dan efektivitas kinerja karyawan. Karyawan cenderung akan meningkatkan kinerjanya baik dari ukuran kuantitas dan kualitas apabila kepuasan karyawan terpenuhi. Tekanan dalam pekerjaan membuat para pimpinan melakukan segala cara agar dapat memenuhi harapan yang telah ditargetkan oleh perusahaan.

Hal ini yang mengakibatkan para 
pimpinan bertindak secara "tegas" dalam mengambil keputusan. Para bawahan menilai sikap tersebut tentunya dengan persepsi yang berbeda. Dengan banyaknya persepsi yang muncul akan sikap pimpinan tersebut memiliki efek pada kinerja karyawannya. Tentunya kinerja karyawan meningkat lebih efektif jika pimpinan dapat bertindak secara tegas dan menjadikan karyawannya menjadi lebih aktif dalam pekerjaannya. Namun akan berbanding terbalik hasilnya jika seorang pimpinan dalam memimpin perusahaan secara diktator, kurang peduli terhadap bawahannya dan bertindak sesuai keinginannya. Sikap pimpinan seperti ini akan sangat berpengaruh pada kinerja karyawannya. Kinerja menjadi tidak efektif, lebih cenderung individualis dalam lingkungan kerjanya yang mengakibatkan dampak negatif pada tercapainya target perusahaan dan kepuasan kerja karyawan yang bersangkutan.

Lingkungan pekerjaan yang kurang kondisif disebabkan kepemimpinan yang kurang berpihak terhadap bawahan dan perusahaan yang dipimpinnya akan mengakibatkan penurunan pada kinerja karyawan tersebut dan tentu berdampak dalam pencapaian perolehan target yang baik secara individual maupun secara umum target perusahaan tersebut. Kepemimpinan bisa disebut sebuah cara seseorang pimpinan (leader) dalam mengerahkan, mendorong dan mengelola unsur yang dimiliki perusahaan secara keseluruhan untuk mewujudkan tujuan perusahaan sehingga menciptakan kinerja para karyawan yang maksimal. Dengan meningkatnya kinerja karyawan, itu artinya pencapaian hasil kerja karyawan untuk mencapai tujuan perusahaan yang dipimpinnya. Untuk meraih tujuan tersebut, harus diupayakan bagaimana cara seorang pimpinan dapat memberikan dorongan semangat dalam bekerja pada tiap karyawannya agar sasaran maupun tujuan yang direncanakan secara bersama dapat tercapai dan target terpenuhi.

Kompensasi memberikan ruang untuk para karyawan menumbuhkan peluang dan membangun persaingan yang ketat untuk memotivasi dalam bekerja yang lebih efisien dan efektif. Hal lainnya yang bisa dilakukan oleh pimpinan selain untuk mendapatkan kepuasan dalam bekerja, tentunya diluar dalam hal meningkatkan kinerja para karyawannya yakni dengan cara mempromosikan karyawannya yang berprestasi itu sendiri Selain itu, pimpinan juga wajib memikirkan apa yang menjadi kesenangan para karyawannya salah satunya dengan cara memberi gaji/ upah yang wajar dan tunjangan yang layak setiap tahunnya serta mempersilahkan karyawannya untuk mengambil jatah cutinya. Dengan memberikan faktor kesenangan tersebut, diharapkan kepuasan atau semangat dalam bekerja tersebut lebih meningkat sehingga mempengaruh dalam pencapaian target yang telah dibebankan perusahaan kepadanya.

Dengan demikian, sebagai seorang pemimpin dengan ambisi serta tanggung jawab dan semangat yang menjulang tinggi dalam memotivasi karyawannya haruslah mempunyai kecerdasan, kedewasaan, keluasaan hubungan sosial dan harus berani mengambil sebuah keputusan agar apa yang direncanakan oleh perusahaan dapat direalisasikan. Selain itu, dalam diri seorang leader wajib mempunyai jiwa kepemimpinan sehingga dapat memimpin para 
bawahannya untuk menggapai apa yang ingin dicapainya dan ditargetkan.

Pimpinan dalam mempromosikan karyawannya untuk jabatan yang lebih tinggi, perusahaan juga mempunyai pertimbangan penilaian terhadap kompetensi yang dimiliki oleh karyawan tersebut yang nantinya dijadikan prasyarat dalam mempromosikan karyawannya. Karyawan dipromosikan berdasarkan nilai dari masing penilaian kompetensi yang berdasarkan kinerja. Skor penilaian dimiliki oleh para karyawan yang diperoleh dari tiap penilaian. Hasil kompetensi karyawan berdasarkan kinerja tersebut inilah yang akan mempresentasikan kelayakan untuk dipromosikan. Kelayakan dalam perihal dipromosikan masih belum dinilai secara objektif oleh pimpinan. Hal tersebut disebabkan seorang karyawan tidak dapat dipromosikan jika penilaian dari pimpinan perusahaan yang rendah walaupun nilai dari kinerjanya tinggi, kepangkatannya tinggi dan pendidikan juga tinggi. Untuk itu, pimpinan perusahaan berperan penting dalam memutuskan karyawan mana yang berhak dipromosikan. Namun, tidak cukup hasil perolehan tertinggi saja dalam menentukan karyawan tersebut layak untuk dipromosikan namun peranan penting dan sangat berpengaruh besar dalam pengambilan keputusan berdasarkan penilaian dari pimpinan untuk menetapkan apakah karyawan tersebut layak untuk mendapatkan promosi jabatan. Dapat disimpulkan dalam respon umum, karyawan bagian dari hasil sebuah persepsi perihal yang berhubungan dengan para karyawannya. Kinerja karyawan yang berlandaskan kepada kepuasan dalam bekerja akan diraih jika terdapat kesesuaian antara sebuah harapan karyawan dengan realita yang ada dan diperolehnya dimana karyawan tersebut bekerja. Didalamnya ada sebuah persepsi karyawan perihal rasa aman, keadilan, enjoy, gairah, kondisi serta kebanggaan. Sebuah persepsi akan lingkungan kerja didalamnya melibatkan interaksi kerja, kondisi dan pengakuan, promosi jabatan serta hubungan harmonis dengan pimpinan. Selain itu juga terdapat kesesuaian antara keinginan karyawan akan kondisi perusahaan dimana karyawan tersebut bekerja diantaranya mengenai pekerjaannya, bakat dan minat serta hal penghasilan dan insentif dengan kemampuan yang dimilikinya.

\section{RUMUSAN MASALAH}

Berdasarkan uraian latar belakang diatas, maka dapat dijabarkan rumusan masalah sebagai berikut :

1. Apakah kepemimpinan, kompensasi dan promosi jabatan berpengaruh terhadap kepuasan kerja karyawan

2. Apakah kepemimpinan, kompensasi dan promosi jabatan berpengaruh langsung terhadap kinerja karyawan

3. Apakah kepuasan kerja berpengaruh terhadap kinerja karyawan

4. Apakah kepuasan kerja merupakan variabel intervening diantara pengaruh kepemimpinan, kompensasi dan promosi jabatan terhadap kinerja karyawan

5. Variabel mana yang berpengaruh dominan terhadap kinerja karyawan

\section{TUJUAN PENELITIAN}

Dalam penelitian bertujuan untuk menganalisis :

1. Pengaruh kepemimpinan, 
kompensasi dan promosi jabatan terhadap kepuasan kerja karyawan

2. Pengaruh langsung kepemimpinan, kompensasi dan promosi jabatan terhadap kinerja karyawan

3. Pengaruh kepuasan kerja terhadap kinerja karyawan

4. Kepuasan kerja merupakan variabel intervening diantara pengaruh kepemimpinan, kompensasi dan promosi jabatan terhadap kinerja karyawan

5. Variabel mana yang berpengaruh dominan terhadap kinerja karyawan

\section{KAJIAN PUSTAKA KEPEMIMPINAN}

Kepemimpinan adalah sebuah cara mempengaruhi seseorang dengan menyampaikan maksud dan tujuan yang ingin dicapai dengan menggunakan petunjuk atau sebuah perintah, sebuah sikap yang mengakibatkan seseorang merespon dan berefek positif, memotivasi serta selalu mengkoordinasikan organisasi, mempunyai skill dalam menumbuhkan rasa percaya diri serta mendukung bawahan untuk mencapai tujuan perusahaan (Dubrin, 2005).

Menurut Gorda (2006), fungsi kepemimpinan yang kaitannya berhubungan dengan upaya penambahan aktivitas dan efisiensi perusahaan, diantaranya :

a. Sebagai innovator (pemimpin yang inovatif perihal pengembangan produk, manajemen efektif efisien maupun secara konseptual menyeluruh yang dilaksanakan guna perkembangan ataupun eksistensi perusahaan)

b. Sebagai communicator (pemimpin yang cakap berkomunikasi dalam menyampaikan target perusahaan yang mudah diterima dan dipahami bawahannya sehingga dapat memunculkan makna bahwa dari komunikan pemimpin harus dapat memahami dan dapat mengambil pokok pembicaraan)

c. Sebagai motivator (pemimpin dapat merangkum serta menjalankan beraneka ragam kebijakan yang bertujuan pada upaya memotivasi karyawan untuk melaksanakan sesuatu kegiatan tertentu dengan kapasitas dan tanggungjawabnya)

d. Sebagai controller (pemimpin melaksanakan pengawasan terhadap berbagai aktivitas perusahaan agar terhindar dari penyimpangan baik terhadap pendayagunaan sumber daya perusahaan atau pelaksanaan perencanaan maupun program kerja guna mencapai tujuan perusahaan secara efektif efisien).

Menurut Siagian (2002), peranan pemimpin dalam perusahaan dapat dilihat dalam 3 (tiga) bentuk berikut ini, diantaranya :

1. Peran interpersonal $\rightarrow$ peran sebagai symbol perusahaan, dimana pimpinan mempunyai tanggung jawab penuh dalam memotivasi dan mengarahkan bawahannya)

2. Peran informasional $\rightarrow$ pimpinan berperan sebagai pemberi dan penerima serta menganalisa informasi yang masuk ke dalam perusahaannya)

3. Peran pengambilan keputusan $\rightarrow$ berperan penting dalam pengambilan kebijakan mengenai strategi bisnis, pengembangan inovasi serta kesempatan dan bernegosiasi dalam menjalankan roda perusahaan 
secara konsisten)

Menurut Siagian (2002), tipe kepemimpinan diantaranya :

1. Tipe kharismatik $\rightarrow$ pemimpin yang mempunyai kekuatan energi, berwibawa dan daya tarik yang luar biasa serta memiliki pengikut yang sangat besar

2. Tipe paternalistis dan maternalistis $\rightarrow$ pemimpin yang menilai bawahannya belum dewasa sehingga bawahan jarang diberi kesempatan untuk berkembang, berinisiatif dalam berkreativitas dan berinovasi serta memiliki sifat selalu benar

3. Tipe otokratis $\rightarrow$ pemimpin yang berkuasa terhadap perusahaan yang dipimpinnya dan cenderung diktator serta menggerakkan bawahannya dengan memaksa

4. Tipe militeristis $\rightarrow$ pemimpin yang berdasarkan pangkat serta jabatan, hampir mirip dengan tipe otokratis dan berlebihan dalam hal formalitas serta menyukai ceremonial

5. Tipe laissez-faire $\rightarrow$ pemimpin yang acuh, tidak ada evaluasi, tidak ada planning untuk perusahaan. Tingkat keberhasilan yang diraih bukan berasal dari kepemimpinan seorang pemimpin melainkan dari kerja keras bawahannya

6. Tipe populistis $\rightarrow$ pemimpin yang terkesan tidak mengikuti perkembangan zaman dan cenderung tidak fleksibel

7. Tipe administratif dan eksekutif $\rightarrow$ pemimpin yang tertib adminitratif dan sesuai dengan prosedural serta mampu menggerakkan modernisasi dan perkembangan perekonomian yang dapat meningkatkan gairah berkerja para bawahannya dan perusahaan
8. Tipe demokratif $\rightarrow$ pemimpin yang mendasarkan bahwa manusia adalah mahluk mulia. Berbanding terbalik dengan tipe paternalistis dan maternalistis, dimana pemimpin sangat terbuka terhadap bawahan dalam hal apapun dan menjadikan bawahan lebih sukses dengan cara mengembangkan kapasitas karyawan tersebut

\section{KOMPENSASI}

Menurut Mondy (2008), kompensasi adalah imbalan yang diberikan kepada karyawan secara keseluruhan sebagai balas jasa. Kompensasi ada 2 (dua) jenis, yakni : (1) kompensasi finasial yang terdiri dari upah, gaji, komisi, bonus dan tunjangan baik yang diterima secara langsung maupun secara tidak langsung serta (2) kompensasi non finansial yang terdiri dari kepuasan dalam bekerja atau dilihat dari faktor psikologis dan fisik dalam wilayah kerja perusahaan.

Menurut Sedarmayanti (2010), tujuan sistem kompensasi diantaranya: 1) Menghargai kinerja; 2) Menjamin keadilan; 3) Pertahankan karyawan, memperoleh karyawan bermutu; 4) Mengendalikan biaya; dan 5) Memenuhi peraturan.

Menurut Hasibuan (2007), kompensasi dipengaruhi oleh beberapa faktor diantaranya :

1. Penawaran dan permintaan kerja $\rightarrow$ kecilnya kompensasi disebabkan oleh banyaknya para pencari kerja, berlaku sebaliknya

2. Kemampuan dan kesediaan $\rightarrow$ besarnya kompensasi yang diberikan berdasarkan atas kondisi perusahaan

3. Serikat buruh perusahaan $\rightarrow$ makin kuat serikat buruhnya maka makin 
besar kompensasi yang diterima

4. Produktivitas kerja karyawan $\rightarrow$ kompensasi berjalan sebanding dengan kinerja yang diberikan oleh para karyawannya

5. Pemerintah dengan UU dan KEPRES $\rightarrow$ suatu keputusan mengenai nominal upah minimum

6. Biaya hidup $\rightarrow$ makin tinggi biaya hidup di suatu daerah, maka makin tinggi pula upah yang diterima dan berlaku sebaliknya

7. Posisi jabatan karyawan $\rightarrow$ kompensasi berjalan sebanding dengan posisi atau jabatan yang dimiliki dikarenakan adanya tanggung jawab yang besar pula

8. Pendidikan dan pengalaman kerja $\rightarrow$ kompensasi diberikan setara dengan background pendidikan serta pengalaman seorang karyawan

9. Kondisi perekonomian nasional $\rightarrow$ jika kondisi perekonomian kondusif atau kuat maka kompensasinya tinggi, begitu juga sebaliknya

10. Jenis dan sifat pekerjaan $\rightarrow$ makin besar resiko dalam bekerja, maka makin besar kompensasi yang diterima

\section{PROMOSI JABATAN}

Menurut Manullang (2006), promosi jabatan berarti penaikan jabatan yakni menerima kekuasan dan tanggung jawab yang lebih besar dari kekuasaan dan tanggung jawab sebelumnya. Menurut Nitisemito (2002), ada beberapa syarat secara umum yang ditetapkan perusahaan untuk mempromosikan karyawannya diantaranya :

a. Pengalaman (ide dan kemampuan terasah seiring dengan banyaknya pengalaman) b. Pendidikan (memiliki pemikiran yang lebih matang dengan pendidikan yang tinggi)

c. Loyalitas (dengan adanya loyalitas diharapkan memiliki tanggung jawab yang sepadan)

d. Kejujuran (unsur syarat yang sangat penting dan umum diperhatikan)

e. Tanggung jawab (sejalan dengan tingkat kejujuran dan sering diperhatikan)

f. Kepandaian bergaul (promosi karyawan diperuntukan bagi yang mudah bergaul)

g. Prestasi kerja (karyawan yang dipromosikan harus melampirkan catatan prestasi kerja)

h. Inisiatif dan kreatif (dijadikan persyaratan untuk mempromosikan karyawan namun tidak dipergunakan oleh seluruh perusahaan)

Menurut Wahyudi (2002), jenis promosi jabatan diantaranya :

1. Promosi sementara $\rightarrow$ promosi yang dilakukan dalam rentan waktu sementara dan tidak diikuti adanya penambahan penghasilan pada karyawan tersebut

2. Promosi tetap $\rightarrow$ promosi yang bersifat mutlak (definitif) dan untuk jangka waktu yang lama

3. Promosi kecil $\rightarrow$ promosi yang pelaksanaannya berupa perbaikan (up grading) guna untuk meningkatkan skill karyawan itu sendiri dan tidak diikuti dengan penambahan unsur lainnya

4. Promosi kering $\rightarrow$ promosi yang ditujukan pada penambahan wewenang serta tanggung jawab namun tidak diikuti dengan peningkatan penghasilan

Menurut Hasibuan (2007), tujuan promosi jabatan diantaranya : 
a) Pemberian pengakuan, posisi serta balas jasa yang lebih tinggi kepada karyawan yang berprestasi

b) Memberikan kepuasan dan kebanggaan tersendiri maupun secara sosial yang makin meningkat dan memiliki penghasilan yang makin tinggi pula

c) Untuk merangsang agar karyawan lebih bergairah bekerja, berdisiplin tinggi dan memperbesar produktivitas kerjanya

d) Untuk menjamin stabilitas karyawan dengan diealisasinya promosi disaat yang tepat berlandaskan kejujuran terhadap seorang karyawan

e) Adanya promosi memberikan keuntungan berkelanjutan karena akan membuka pengrekrutan karyawan baru

f) Kesempatan untuk berkreasi dan berinovasi lebih terbuka

g) Meningkatkan ilmu pengetahuan bagi karyawan lainnya serta menambah pengalaman kerja

h) Menempati posisi kerja yang kosong dikarenakan berhenti bekerja

i) Ditempatkan pada posisi yang tepat guna meningkatkan produktivitas kerja

j) Merangsang para pelamar agar tertarik untuk bekerja di perusahaan tersebut dikarenakan adanya jenjang karir yang jelas

k) Memperbaiki karir karyawan tersebut

\section{KEPUASAN KERJA}

Menurut Handoko (2012), kepuasan kerja merupakan kondisi emosional yang bersifat menyenangkan maupun yang tidak atas suatu pekerjaan. Hal ini erat kaitannya dengan sikap karyawan pada beberapa hal yang berkaitan dengan pekerjaan, misalnya : situasi dan kondisi pekerjaan, lingkungan sosial, upah kerja serta kepemimpinan. Menurut Handoko (2012), karyawan yang mendapatkan kepuasan kerja biasanya mempunyai catatan kehadiran yang lebih baik, cenderung lebih menonjol dalam hal prestasi dibandingkan karyawan yang merasa tidak puas dalam bekerja namun kurang terlihat aktif dalam perihal aktivitas serikat buruh.

Menurut Luthans (2006), beberapa hal berikut dapat meningkatkan kepuasan kerja, diantaranya :

1. Membuat pekerjaan menjadi menyenangkan

2. Memiliki gaji, tunjangan, dan berjenjang karir (promosi) yang adil

3. Menyesuaikan orang dengan kesesuaian minat dan keahlian

4. Merancang pekerjaan agar menarik dan menyenangkan

Menurut Luthans (2006), kepuasan kerja dipengaruhi oleh beberapa faktor diantaranya : 1) Gaji; 2) Pekerjaan itu sendiri; 3) Kelompok kerja; 4) Pengawasan; 5) Promosi naik jabatan dan 6) Kondisi kerja.

\section{KINERJA}

Menurut Bastian (2006), kinerja merupakan sebuah gambaran sukses dalam perihal pelaksanaan suatu program kerja atau sebuah kebijakan untuk mewujudkan suatu visi, misi, tujuan serta sasaran perusahaan. Penilaian kinerja yang dilakukan secara continue akan memiliki feed back sehingga hal ini akan memberikan evaluasi secara terus-menerus untuk menciptakan sebuah keberhasilan dimasa depan. Menurut Moeheriono (2009), terdapat 3 (tiga) jenis kinerja yang umum didalam 
sebuah organisasi yaitu :

a. Kinerja operasional $\rightarrow$ berkaitan dengan penggunaan sumber daya oleh perusahaan secara efektif

b. Kinerja administrative $\rightarrow$ berkenaan dengan administrasi organisasi, dimana didalamnya meliputi struktur yang mengatur suatu hubungan karyawan yang mempunyai jabatan mengenai otoritas wewenang dan tanggung jawabnya

c. Kinerja strategik $\rightarrow$ berkaitan dengan kinerja perusahaan, adaptasi perusahaan, dan ketetapan dalam evaluasi analisa lingkungan khususnya dalam menjalankan visi misinya

Menurut Mahsun (2009), ada 4 (empat) elemen pokok dalam pengukuran kinerja diantaranya :

1. Menetapkan tujuan, sasaran dan strategi organisasi

2. Menyusun indikator pengukuran kinerja

3. Mengukur tingkat keberhasilan pencapaian sasaran organisasi

4. Evaluasi terhadap sebuah kinerja (perkembangan organisasi, peningkatan kualitas, pemberian nilai, tolak balik/ respon, pengambilan keputusan hingga dari sisi akuntabilitas)

Menurut Mulyadi (2001), pengukuran sebuah kinerja mempunyai tujuan inti yakni memberikan motivasi kepada karyawan guna maksimal dalam pencapaian sasaran serta pemenuhan standar perilaku agar tercipta sikap dan hasil yang sesuai keinginan. Tujuan tersebut merupakan sebuah catatan pembuktian keberhasilan termasuk seluruh elemen yang ada didalamnya. Menurut Mulyadi (2001), penilaian kinerja memiliki beberapa manfaat diantaranya : a) Pengelolaan operasional organisasi yang efektif efisien melalui motivasi karyawan secara maksimum

b) Pengambilan keputusan bersama karyawan

c) Identifikasi kebutuhan akan diklat dan pengembangan serta proses seleksi dan evaluasinya

d) Evaluasi kinerja bagi atasan mereka perihal penilaian kinerja dalam upaya feed back dari seorang karyawan

e) Menyiapkan pondasi yang tepat untuk pembagian penghargaan

Menurut Sastrohadiwiryo (2003), kinerja karyawan dipengaruhi oleh beberapa faktor diantaranya : diklat, disiplin kerja, kompensasi, iklim organisasi, sistem jenjang karir, motivasi, kepemimpinan

\section{PENELITIAN TERDAHULU}

Berikut beberapa penelitian terdahulu dalam penelitian ini yang digunakan oleh peneliti sebagai bahan kajian, antara lain :

1. Moh. Ali Shabab (2014) "The Influence of Leadership and Work Attitudes Toward Job Satisfaction and Performance of Employee". Tujuan dari penelitian ini untuk mengetahui pengaruh kepemimpinan dan sikap kerja terhadap kepuasan kerja dan kinerja SDM Rumah Sakit Konawe Sulawesi Tenggara baik secara simultan maupun secara parsial. Objek penelitian yaitu di Rumah Sakit Konawe Sulawesi Tenggara. Jumlah responden yakni sebanyak 79 responden yang berstatus sebagai PNS. Hasil dari penilitian ini adalah kepemimpinan dan sikap kerja berpengaruh positif dan signifikan terhadap kepuasan kerja, kepuasan kerja berpengaruh 
positif dan signifikan terhadap kinerja, serta kepemimpinan berpengaruh positif namun tidak signifikan terhadap kinerja karyawan sedangkan sikap kerja berpengaruh positif dan signifikan terhadap kinerja karyawan.

2. Sofiah (2013) "The Effect of Compensation Toward Job Satisfaction and Job Performance of Outsourcing Employees of Syariah Banks in Malang Indonesia". Populasi penelitian berjumlah sebanyak 436 orang dengan sampel sebanyak 141 orang karyawan outsourcing. Sampel diambil dengan menggunakan teknik sampel acak. Objek penelitian yakni di salah satu Bank Syariah di Kota Malang Indonesia. Penelitian ini menguji pengaruh kompensasi terhadap kepuasan kerja yang akan berdampak terhadap kinerja karyawan outsourcing di salah satu Bank Syariah di Kota Malang. Hasil penelitian ini menunjukkan bahwa kompensasi finansial maupun non finansial berpengaruh positif dan signifikan terhadap kinerja karyawan outsourcing baik secara langsung maupun tidak langsung melalui kepuasan kerja.

3. Deni Syaifuddin (2015) "Pengaruh

Motivasi Dan Promosi Jabatan Terhadap Kinerja SDM dengan Kepuasan kerja sebagai Variabel Intervening pada Bank Mandiri Cabang Jepara". Tujuan penelitian ini adalah untuk menganalisis pengaruh motivasi, dan promosi jabatan terhadap kepuasan kerja, serta untuk menganalisis pengaruh motivasi, promosi jabatan, kepuasan kerja terhadap kinerja SDM.
Penelitian ini menggunakan populasi seluruh karyawan Bank Mandiri Cabang Jepara, dengan sampel berjumlah sebanyak 53 responden yang diperoleh menggunakan metode sensus. Peneliti menggunakan path analysis sebagai metode analisa datanya. Hasil penelitian variabel motivasi berpengaruh terhadap kepuasan kerja pegawai dan kinerja SDM dengan arah regresi yang positif. Untuk variabel promosi jabatan berpengaruh terhadap kepuasan kerja pegawai dan kinerja SDM dengan arah regresi yang positif. Kepuasan kerja berpengaruh terhadap kinerja SDM dengan arah regresi yang positif. Kepuasan kerja bukan variabel intervening diantara pengaruh motivasi terhadap kinerja SDM. Kepuasan kerja bukan variabel intervening diantara pengaruh promosi jabatan terhadap kinerja SDM.

\section{KERANGKA BERPIKIR}

Terdapat kerangka berpikir penelitian yang menggambarkan alur pengaruh antar variabel penelitian. Berikut dibawah ini merupakan kerangka berpikir penelitian :

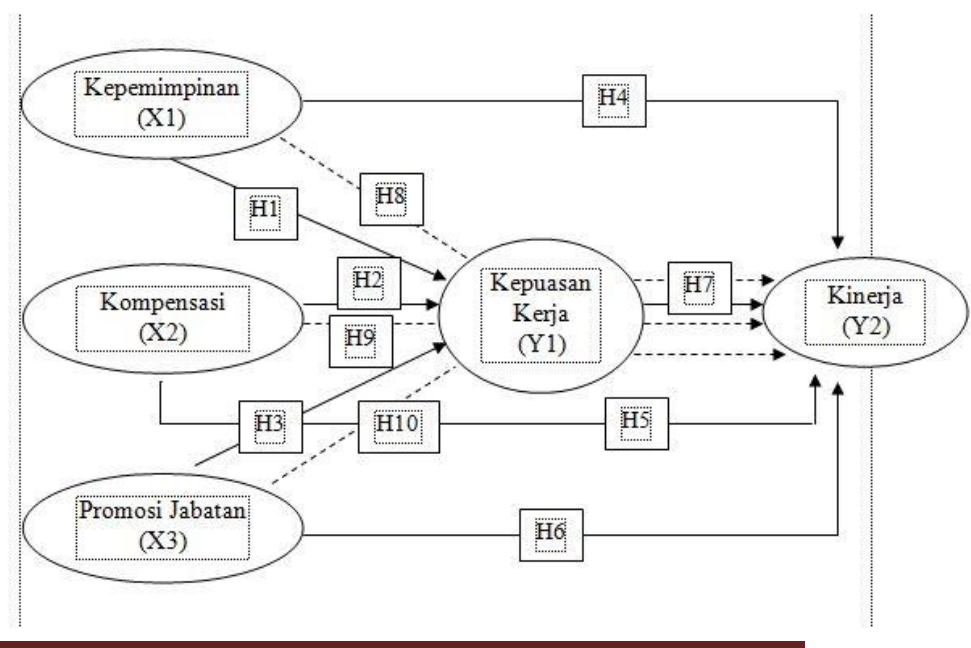




\section{HIPOTESA}

Adapun hipotesis penelitian tersebut meliputi :

$\mathrm{H} 1$ : Kepemimpinan berpengaruh terhadap kepuasan kerja karyawan

$\mathrm{H} 2$ : Kompensasi berpengaruh terhadap kepuasan kerja karyawan

H3 : Promosi Jabatan berpengaruh terhadap kepuasan kerja karyawan

$\mathrm{H} 4$ : Kepemimpinan berpengaruh langsung terhadap kinerja karyawan

H5 : Kompensasi berpengaruh langsung terhadap kinerja karyawan

H6 : Promosi Jabatan berpengaruh langsung terhadap kinerja karyawan

$\mathrm{H} 7$ : Kepuasan kerja berpengaruh terhadap kinerja karyawan

H8 : Kepuasan kerja merupakan variabel intervening diantara pengaruh kepemimpinan terhadap kinerja karyawan

H9 : Kepuasan kerja merupakan variabel intervening diantara pengaruh kompensasi terhadap kinerja karyawan

$\mathrm{H} 10$ : Kepuasan kerja merupakan variabel intervening diantara pengaruh promosi jabatan terhadap kinerja karyawan

H11 : Promosi Jabatan berpengaruh dominan terhadap kinerja karyawan.

\section{METODOLOGI PENELITIAN JENIS PENELITIAN}

Jenis penelitiannya yakni penelitian eksplanatori yaitu sebuah penelitian yang mempunyai tujuan untuk menguji dan menghasilkan hubungan pengaruh variabel bebas $(X)$ terhadap variabel terikat $(\mathrm{Y})$ pada penelitian baik secara parsial maupun simultan (Sugiyono, 2011).

\section{OBJEK PENELITIAN}

Obyek penelitian menjadi sangat penting dalam suatu penelitian, hal ini erat hubungannya antara judul penelitian dengan data yang diperlukan. Jika penentuan obyek penelitian ternyata tidak mendukung judul dan data penelitian, tentu saja merupakan kendala besar dan mempengaruhi hal penelitian tersebut (Sunyoto, 2013). Obyek penelitian yang digunakan adalah perbankan daerah yang menyokong pertumbuhan dan perputaran roda perekonomian daerah itu sendiri tepatnya di wilayah Jawa Timur. Untuk lokasi penelitian ini beralamatkan di Jl. Sudirman No. 5 Pamekasan.

\section{TEKNIK PENGUMPULAN DATA}

Secara terperinci, penelitian ini menggunakan metode pengumpulan data sebagai berikut : Kuesioner dan Dokumentasi

\section{TEKNIK ANALISA DATA}

Teknik analisis yang dipergunakan sebagai alat yang akan menganalisa data yang telah terkumpul dari beberapa hipotesa yang ada pada penelitian ini yakni menggunakan analisa PLS (partial least square). Menurut Wold dalam Ghozali (2014), PLS adalah alat analisa yang tidak berdasarkan pada banyak asumsi dan sangat powerfull dan data yang digunakan tidak harus berdistribusi normal multivariate (menggunakan indikator skala kategori, interval, ordinal dan penggunaan ratio pada model yang sama) serta tidak membutuhkan jumlah sampel yang banyak 


\section{ANALISA DAN PEMBAHASAN ANALISA HASIL PENELITIAN EVALUASI MODEL PENGUKURAN (OUTER MODEL)}

Pada analisa pertama ini, model pengukuran dipergunakan guna mengukur convergent validity, discriminant validity dan composite reliability. Berikut adalah gambar model pengukuran yang dikembangkan pada penelitian berikut ini :

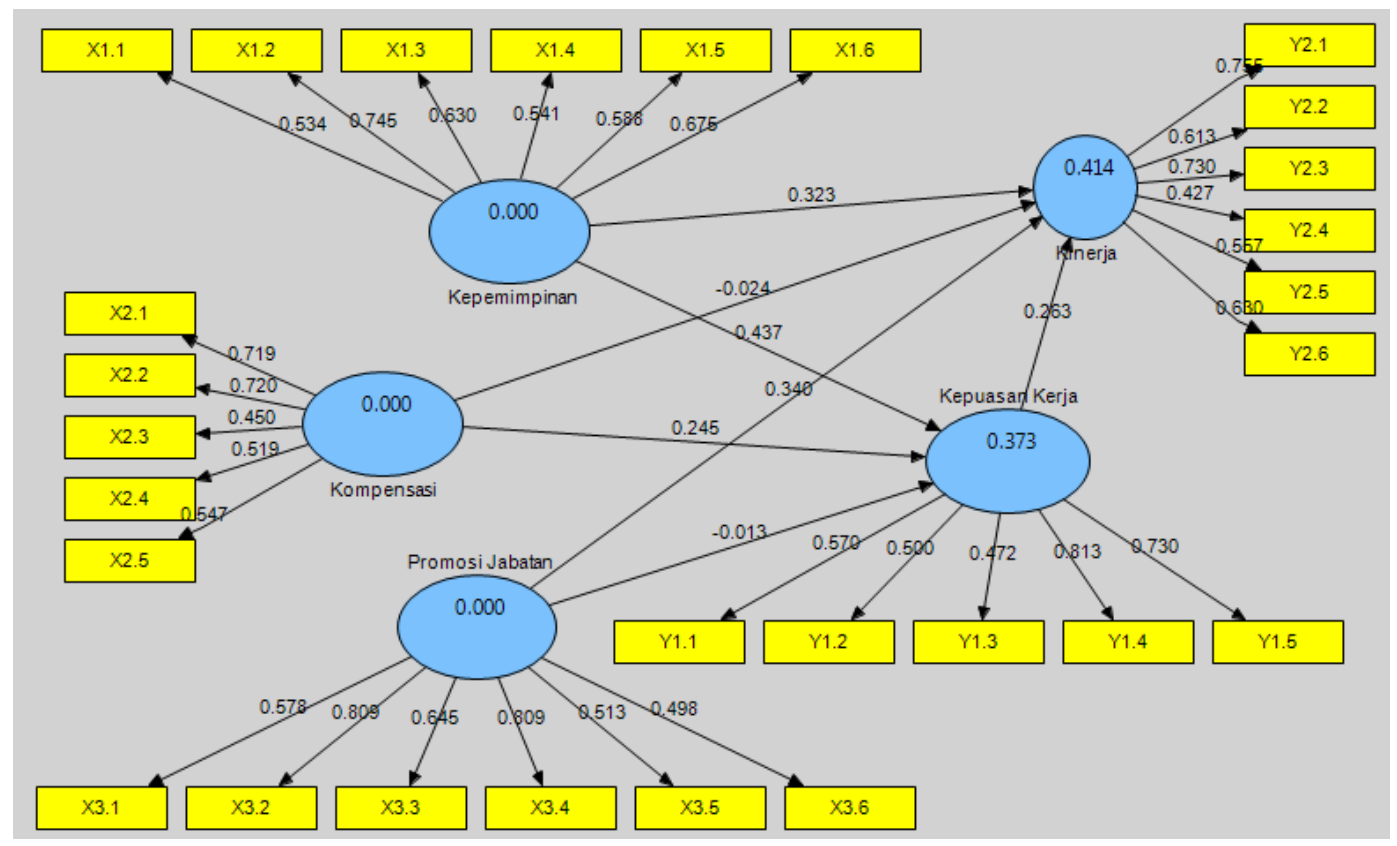

Gambar 1.1

Outer Model

\section{VALIDITAS KONVERGEN (CONVERGENT VALIDITY)}

Evaluasi pertama pada outer model yakni convergent validity. Guna mengukur convergent validity peneliti menggunakan nilai outer loading dimana suatu indikator dikatakan memenuhi convergent validity jika memiliki nilai outer loading $>0,4$.

\section{VALIDITAS DISKRIMINAN (DISCRIMINANT VALIDITY)}

Evaluasi kedua pada outer model yakni discriminant validity. Guna mengukur discriminant validity peneliti menggunakan nilai cross loading. Suatu indikator dikatakan memenuhi discriminant validity jika nilai cross loading indikator terhadap konstruknya adalah yang terbesar dibandingkan terhadap konstruk lainnya.

Pengujian discriminant validity selain dengan menggunakan nilai cross loading seperti yang telah terlampir pada tabel diatas, discriminant validity juga dapat dilihat dari nilai akar average variance extracted (AVE) untuk setiap konstruk dan membandingkannya dengan 
korelasi antar konstruk. Hasil dikatakan baik apabila hasil akar AVE untuk setiap konstruknya dalam model ini lebih tinggi dari nilai korelasi antara konstruk tersebut dengan konstruk lainnya. Berikut hasil AVE dan nilai akar AVE, tersaji dalam tabel dibawah ini :

Tabel 1.1

Hasil dan Nilai Akar Average Variance Extracted

\begin{tabular}{|l|c|c|}
\hline & AVE & Akar AVE \\
\hline Kepemimpinan & 0.388466 & 0.623270407 \\
\hline Kepuasan Kerja & 0.398293 & 0.631104587 \\
\hline Kinerja & 0.394665 & 0.628223686 \\
\hline Kompensasi & 0.360997 & 0.600830259 \\
\hline Promosi Jabatan & 0.42838 & 0.654507448 \\
\hline
\end{tabular}

Sumber : data diolah

Untuk nilai korelasi antar konstruk sebagai perbandingan dengan AVE dalam pengujian discriminant validity terdapat dalam tabel dibawah ini :

Tabel 1.2

Nilai Korelasi Antra Konstruk

\begin{tabular}{|l|l|l|l|l|l|}
\hline & Kepemimpinan & $\begin{array}{c}\text { Kepuasan } \\
\text { Kerja }\end{array}$ & Kinerja & Kompensasi & $\begin{array}{c}\text { Promosi } \\
\text { Jabatan }\end{array}$ \\
\hline Kepemimpinan & 1 & & & & \\
\hline Kepuasan Kerja & 0.577833 & 1 & & & \\
\hline Kinerja & 0.501707 & 0.473696 & 1 & & \\
\hline Kompensasi & 0.579214 & 0.495143 & 0.385165 & 1 & \\
\hline Promosi Jabatan & 0.117083 & 0.103947 & 0.399335 & 0.267558 & 1 \\
\hline
\end{tabular}

Sumber : diolah

\section{COMPOSITE RELIABILITY}

Composite reliability menguji nilai reliabilitas indikator-indikator pada suatu konstruk. Suatu konstruk atau variabel dikatakan memenuhi composite reliability jika memiliki nilai composite reliability $>0,7$. Dalam model pengukuran penelitian ini, masing-masing variabel telah memenuhi composite reliability. Berikut ini merupakan nilai composite reliability masing-masing konstruk atau variabel diantaranya :

\section{EVALUASI MODEL STRUKTURAL (INNER MODEL)}

Dalam evaluasi inner model ini akan mengukur nilai R-square dan uji kasualitas. Berikut adalah gambar model struktural yang dikembangkan pada penelitian berikut ini : 


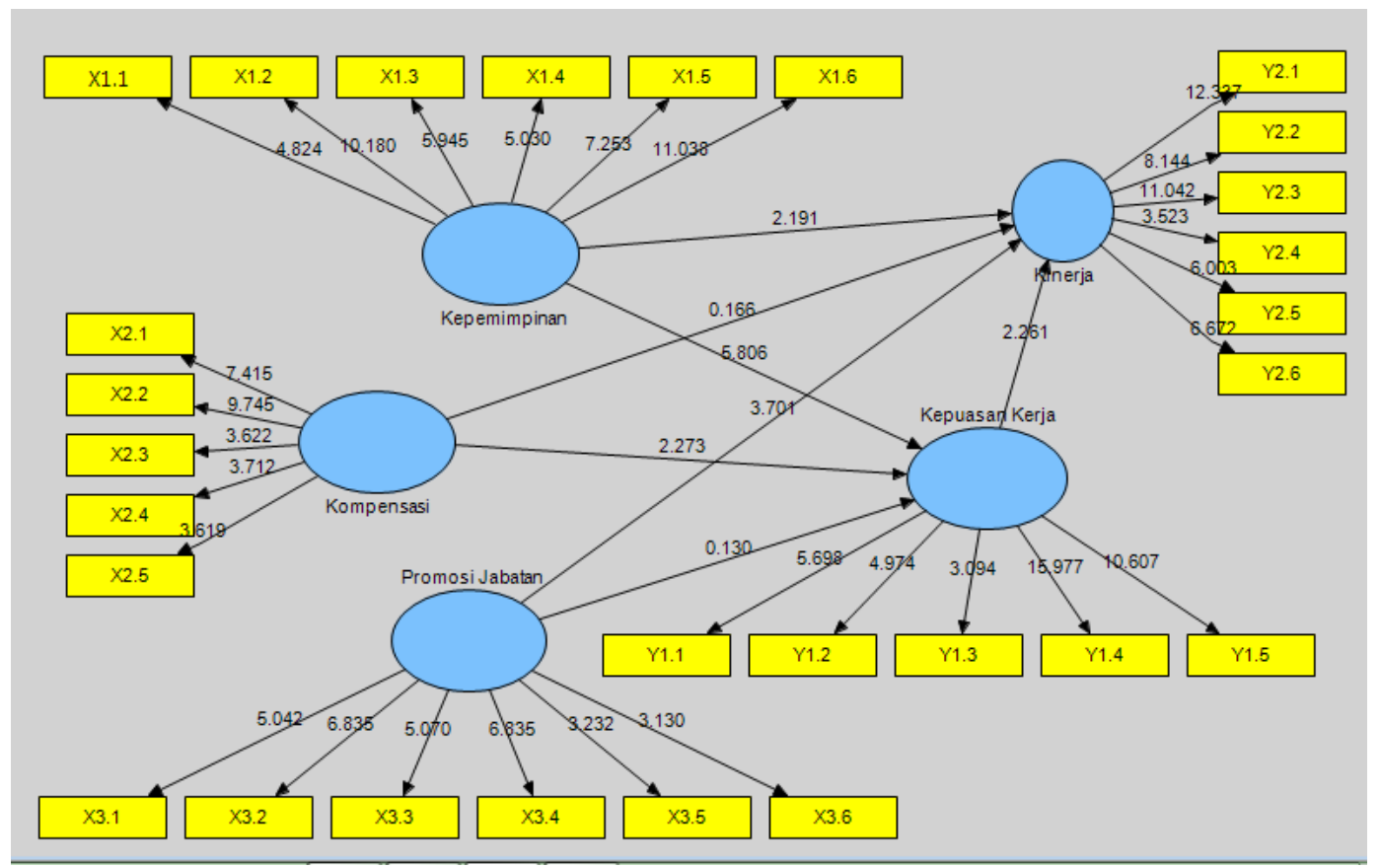

Gambar 1.2

Inner Model

\section{NILAI R-SQUARE}

Evaluasi pertama pada inner model dilihat dari nilai R-square atau koefisien determinasi. Dalam analisa Goodness of fit pada model PLS dapat diketahui dari nilai $Q^{2}$. Nilai $Q^{2}$ memiliki arti yang sama dengan koefisien determinasi $R^{2}$ (R-Square) dalam analisis regresi. Semakin tinggi $R^{2}$, maka model dapat dikatakan semakin fit dengan data. Berdasarkan pengolahan data dengan PLS, dihasilkan nilai R-square sebagai berikut :

Tabel 1.3

Nilai $R$-square

\begin{tabular}{|l|c|}
\hline & R Square \\
\hline Kepuasan Kerja & 0.372788 \\
\hline Kinerja & 0.413773 \\
\hline
\end{tabular}

Sumber : data diolah

\section{UJI KASUALITAS}

Selanjutnya adalah uji kausalitas dan digunakan untuk menguji hipotesis penelitian pengaruh kepemimpinan, kompensasi dan promosi jabatan terhadap kepuasan kerja dan kinerja karyawan. Hipotesis penelitian dapat diterima jika nilai t-hitung (t-statistic) lebih besar dari t-tabel pada tingkat kesalahan (a) 5\% yaitu sebesar 1,96. Dibawah ini adalah hasil nilai koefisien path (original sample estimate) dan hasil nilai t-hitung (t-statistic) pada inner model dalam penelitian ini yang tersaji dalam tabel dibawah ini : 
Tabel 1.4

Nilai Koefisien Path dan Nilai t-hitung

\begin{tabular}{|l|c|c|c|l|}
\hline & $\begin{array}{c}\text { Original Sample } \\
\mathbf{( 0 )}\end{array}$ & $\begin{array}{c}\text { Standard Error } \\
\text { (STERR) }\end{array}$ & $\begin{array}{c}\text { T Statistics } \\
(\mid \mathbf{O} / \text { STERR })\end{array}$ & Keterangan \\
\hline $\mathrm{X} 1 \rightarrow \mathrm{Y} 1$ & 0.437239 & 0.075304 & 5.806312 & Signifikan \\
\hline $\mathrm{X} 1 \rightarrow \mathrm{Y} 2$ & 0.323482 & 0.14763 & 2.191173 & Signifikan \\
\hline $\mathrm{Y} 1 \rightarrow \mathrm{Y} 2$ & 0.26304 & 0.11634 & 2.260951 & Signifikan \\
\hline $\mathrm{X} 2 \rightarrow \mathrm{Y} 1$ & 0.245336 & 0.107922 & 2.273282 & Signifikan \\
\hline $\mathrm{X} 2 \rightarrow \mathrm{Y} 2$ & -0.023523 & 0.141368 & 0.166395 & Tidak Signifikan \\
\hline $\mathrm{X} 3 \rightarrow \mathrm{Y} 1$ & -0.012888 & 0.099294 & 0.129794 & Tidak Signifikan \\
\hline $\mathrm{X} 3 \rightarrow \mathrm{Y} 2$ & 0.340412 & 0.091974 & 3.701182 & Signifikan \\
\hline
\end{tabular}

Sumber : data diolah

Untuk mengetahui pengaruh secara tidak langsung antara variabel kepemimpinan, kompensasi dan promosi jabatan terhadap kinerja karyawan melalui kepuasan kerja dapat dilakukan dengan mengalikan koefisien path pengaruh secara langsung variabel kepemimpinan, kompensasi dan promosi jabatan terhadap kepuasan kerja dengan pengaruh secara langsung kepuasan kerja terhadap kinerja karyawan pada PT. Bank Jatim, Tbk Cabang Pamekasan. Adapun hasil perhitungan pengaruh secara tidak langsung (indirect effect) adalah sebagai berikut :

Tabel 1.5

Indirect Effect

\begin{tabular}{|l|l|c|c|c|}
\hline \multicolumn{2}{|c|}{$\begin{array}{c}\text { Pengaruh Varibel Eksogen } \rightarrow \\
\text { Kepuasan Kerja }\end{array}$} & $\begin{array}{c}\text { Kepuasan } \\
\text { Kerja } \rightarrow \text { Kinerja }\end{array}$ & $\begin{array}{c}\text { Indirect } \\
\text { effect }\end{array}$ & Keterangan \\
\cline { 1 - 1 } $\begin{array}{l}\text { Kepemimpinan } \rightarrow \\
\text { Kepuasan Kerja }\end{array}$ & 0.437239 & & 0.115011347 & Intervenig \\
\cline { 1 - 2 } $\begin{array}{l}\text { Kompensasi } \rightarrow \\
\text { Kepuasan Kerja }\end{array}$ & 0.245336 & 0.26304 & 0.064533181 & Intervenig \\
\cline { 1 - 2 } $\begin{array}{l}\text { Promosi Jabatan } \rightarrow \\
\text { Kepuasan Kerja }\end{array}$ & -0.012888 & & -0.00339006 & $\begin{array}{c}\text { Bukan } \\
\text { Intervenig }\end{array}$ \\
\hline
\end{tabular}

Sumber : data diolah

\section{PEMBAHASAN VALIDITAS KONVERGEN}

Berdasarkan hasil tabel diatas memperlihatkan bahwa Nilai outer loading indicator variabel kepemimpinan diantaranya kualitas kerja, kuantitas kerja, ketepatan waktu, efektivitas, kemandirian, dan komitmen; Nilai outer loading indicator variabel kompensasi diantaranya gaji, insentif, bonus, tunjangan dan asuransi; Nilai outer loading indicator variabel promosi jabatan diantaranya kemampuan sebagai pengawas, kebutuhan prestasi, kecerdasan, ketegasan, percaya diri dan 
inisiatif; Nilai outer loading indicator variabel kepuasan kerja diantaranya pekerjaan itu sendiri, pimpinan, rekan kerja, promosi jabatan dan gaji; serta Nilai outer loading indicator variabel kinerja karyawan diantaranya kecakapan, kejujuran, prestasi kerja, wewenang, kepemimpinan dan disiplin secara keseluruhan lebih dari 0,4.

Hal ini juga memperlihatkan bahwa semua indikator yang menyusun variabel kepemimpinan, kompensasi, promosi jabatan, kepuasan kerja hingga kinerja karyawan yang digunakan dalam penelitian ini telah memenuhi convergent validity sehingga semua indikator tersebut dapat digunakan untuk analisa lebih lanjut.

\section{VALIDITAS DISKRIMINAN}

Berdasarkan tabel diatas, maka bisa dikatakan indikator yang dipergunakan dalam penelitian berikut ini telah memiliki discriminat validity yang baik dalam menyusun variabelnya masing-masing.

Untuk hasil nilai akar kuadrat AVE dan nilai antar konstruk. Nilai korelasi antar konstruk tersebut lebih kecil jika dibandingkan dengan hasil akar AVE kepemimpinan, kompensasi dan promosi jabatan maka dapat disimpulkan konstruk kepemimpinan, kompensasi dan promosi jabatan sudah memiliki discriminant validity yang baik. Serta hasil akar AVE kepuasan kerja dan kinerja karyawan lebih besar jika dibandingkan dengan nilai korelasi antar konstruk tersebut, dengan demikian dapat disimpulkan konstruk kepuasan kerja sudah memiliki discriminant validity yang baik.

COMPOSITE RELIABILITY
Berdasarkan tabel diatas menunjukkan nilai composite reliability untuk variabel kepemimpinan, kompensasi, promosi jabatan, kepuasan kerja dan kinerja karyawan secara keseluruhan semuanya lebih dari 0,7. Hal ini memperlihatkan bahwa dalam model pengukuran penelitian ini masing-masing variabel telah memenuhi composite reliability.

\section{NILAI R-SQUARE}

Berdasarkan hasil data pada tabel diatas, maka model struktural dalam penelitian ini adalah baik. Hal ini disebabkan karena nilai yang diperoleh sebesar $37,28 \%$ dan $41,38 \%$ merupakan nilai diatas 33\% yang merupakan indikator penilaian moderat.

\section{UJI KASUALITAS}

Berdasarkan tabel diatas, dijelaskan secara rinci pengujian hipotesis penelitian ini diantaranya :

a. Hipotesis $1 \rightarrow$ Hasil ini menunjukkan terdapat pengaruh positif yang signifikan antara kepemimpinan terhadap kepuasan kerja, artinya semakin baik kepemimpinan dapat menumbuhkan kepuasan kerja karyawan. Berdasarkan hasil ini, hipotesis pertama diterima.

b. Hipotesis $2 \rightarrow$ Hasil ini menunjukkan terdapat pengaruh positif yang signifikan antara kompensasi terhadap kepuasan kerja, artinya semakin layak kompensasi yang diterima oleh karyawan maka akan dapat memberikan rasa puas terhadap karyawan. Berdasarkan hasil ini, hipotesis kedua diterima.

c. Hipotesis $3 \rightarrow$ Hasil ini menunjukkan tidak terdapat pengaruh yang signifikan antara promosi jabatan 
terhadap kepuasan kerja karyawan. Berdasarkan hasil ini, hipotesis ketiga ditolak. Hal ini terjadi disebabkan oleh beberapa factor diantaranya : sistem promosi jabatan yang ada dalam perusahaan ini kurang merata, kurang terbuka dan kurang selektif sehingga hal ini mengakibatkan tingkat kepuasan kerja karyawan kurang maksimal jika dinillai dari pengaruh promosi jabatan, namun hal ini akan memacu karyawan untuk meningkatkan kinerjanya. Hal ini dilakukan untuk menunjukkan kepada pimpinan bahwa karyawan yang bersangkutan layak mendapatkan promosi jabatan tersebut.

d. Hipotesis $4 \rightarrow$ Hasil ini menunjukkan terdapat pengaruh positif yang signifikan antara kepemimpinan terhadap kinerja karyawan, artinya semakin baik kepemimpinan maka akan berdampak pada meningkatnya kinerja karyawan. Berdasarkan hasil ini, hipotesis keempat diterima.

e. Hipotesis $5 \rightarrow$ Hasil ini menunjukkan tidak terdapat pengaruh yang signifikan antara kompensasi terhadap kinerja karyawan. Berdasarkan hasil ini, hipotesis kelima ditolak. Hal ini disebabkan oleh beberapa factor diantaranya : kompensasi yang diberikan dalam hal ini kompensasi yang tidak langsung seperti tunjangan jaminan hari tua, asuransi kesehatan dirasa kurang bisa dirasakan oleh karyawan. Hal ini akan dapat dirasakan oleh karyawan setelah pensiun, untuk masa kerja karyawan dalam perusahaan ini belum tentu selamanya akan bertahan dalam perusahaan tersebut. Hal lain seperti bonus yang dijanjikan oleh perusahaan, terasa sulit dirasakan karyawan dikarenakan target yang diberikan oleh perusahaan begitu tinggi sehingga untuk memperoleh bonus tersebut sangat sulit. Pada dasarnya, kompensasi yang diterima oleh karyawan sudah dirasa puas namun hal ini belum dapat meningkatkan kinerja karyawan secara optimal.

f. Hipotesis $6 \rightarrow$ Hasil ini menunjukkan terdapat pengaruh positif yang signifikan antara promosi jabatan terhadap kinerja karyawan, artinya semakin baik sistem promosi jabatan di perusahaan tersebut maka akan dapat meningkatkan kinerja karyawan. Berdasarkan hasil ini, hipotesis keenam diterima.

g. Hipotesis $7 \rightarrow$ Hasil ini menunjukkan terdapat pengaruh positif yang signifikan antara kepuasan kerja terhadap kinerja karyawan, artinya semakin tinggi tingkat kepuasan yang dirasakan oleh karyawan maka akan dapat meningkatkan kinerja karyawan. Berdasarkan hasil ini, hipotesis ketujuh diterima.

h. Hipotesis $8 \rightarrow$ Berdasarkan hasil ini, hipotesis kedelapan dalam penelitian ini diterima.

i. Hipotesis $9 \rightarrow$ Berdasarkan hasil ini, hipotesis kesembilan dalam penelitian ini diterima.

j. Hipotesis $10 \rightarrow$ Berdasarkan hasil ini, hipotesis kesepuluh dalam penelitian ini ditolak. Kepuasan kerja yang bukan variabel intervening antara pengaruh promosi jabatan terhadap kinerja karyawan disebabkan oleh tingkat kepuasan kerja yang dirasakan oleh karyawan dalam peningkatan kinerja bukan melalui promosi jabatan. Tanpa adanya kepusan kerja, seorang karyawan 
akan terus meningkatkan kinerjanya agar dapat dipilih oleh pimpinan untuk meraih kesempatan dipromosikan ke jabatan yang lebih tinggi. Adanya peningkatan kinerja seorang karyawan yakni bertujuan untuk memperoleh jabatan yang lebih tinggi atau memperoleh kesempatan agar bisa dipromosikan ke level yang lebih tinggi. Untuk kepuasan kerja, sudah terpenuhi oleh jumlah kompensasi yang diterima oleh seorang karyawan dan kepemimpinan yang sempurna dari sosok pemimpin dalam memimpin perusahaan tersebut.

k. Hipotesis $11 \rightarrow$ Berdasarkan hasil ini, hipotesis terakhir dalam penelitian ini diterima.

\section{KESIMPULAN DAN SARAN}

Dari beberapa hasil analisa dan pembahasan diatas, dapat ditarik sebuah kesimpulan bahwa adanya kepuasan kerja dalam perusahaan ini dipengaruhi oleh kepemimpinan yang ideal dan kompensasi yang memadai. Untuk meningkatkan kinerja para karyawan lebih optimal, faktor kepemimpinan seorang pimpinan dalam memimpin perusahaan dan guna meraih kesempatan untuk promosi jabatan ke level yang lebih meningkat memiliki pengaruh yang signifikan dalam perusahaan ini. Beberapa saran terhadap manajemen perusahaan agar dapat memperbaiki kinerja karyawan agar lebih optimal diantaranya untuk munculnya kepuasan dalam bekerja yang besar terhadap karyawan harus dilakukan sistem promosi yang lebih terbuka, selektif dan memberi kesempatan ke semua elemen karyawan baik dari karyawan junior hingga yang senior. Untuk meningkatkan serta mempertahankan kinerja para karyawan agar lebih efektif dan efisien, kompensasi yang diterima oleh karyawan harus lebih layak sehingga dapat memenuhi kebutuhan hidup para karyawan. Hal tersebut akan sangat membantu para karyawannya untuk meningkatkan kinerjanya dan akan membuat rasa nyaman berada dalam lingkungan perusahaan karyawan tersebut bekerja

\section{DAFTAR PUSTAKA}

Bastian, Indra. 2006. Akuntansi Sektor Publik Suatu Pengantar. Erlangga: Jakarta.

Dubrin, Andrew J. 2005. Leadership (Terjemahan) Edisi Kedua. Prenada Media: Jakarta.

Gorda, I Gusti Ngurah. 2006. Manajemen Sumber Daya Manusia Edisi Revisi. Astabrata: Bali.

Handoko, Hani. 2012. Manajemen Personalia Dan Sumber Daya Manusia. BPFE: Yogyakarta.

Hasibuan, Malayu. 2007. Manajemen Sumber Daya Manusia Edisi Kesepuluh. PT. Gunung Agung: Jakarta.

Hasibuan, Malayu. 2007. Manajemen Sumber Daya Manusia. PT. Bumi Aksara: Jakarta.

Luthans, Fred. 2006. Organizational Behavior. Mc Graw-Hill Book Co Singapore: Singapura.

Luthans, Fred. 2006. Perilaku Organisasi. Andi: Yogyakarta.

Mahsun, Muhamad. 2009. Pengukuran Kinerja Sektor Publik Edisi Pertama. BPFE: Yogyakarta.

Manullang, Marihot. 2006. Manajemen Personalia. Gajah Mada University Press: Yogyakarta. 
Moeheriono. 2009. Pengukuran Kinerja Berbasis Kompetensi. Ghalia Indonesia: Bogor.

Mondy, Wayne. 2008. Manajemen SDM Jilid 2. Erlangga: Jakarta.

Mulyadi. 2001. Akuntansi Manajemen Konsep, Manfaat dan Rekayasa. Salemba Empat: Jakarta.

Nitisemito, S. 2002. Perilaku Organisasi Perusahaan. Salemba Empat: Jakarta.

Saifuddin, Deni. 2015. Peningkatan Kinerja Melalui Motivasi Dan Promosi Jabatan Dengan Kepuasan Kerja Sebagai Variabel Intervening Pada PT. Bank Mandiri Cabang Jepara. Unpublished undergraduate thesis. Fakultas Ekonomi Universitas Islam Sultan Agung Semarang.

Sastrohadiwiryo, Siswanto. 2003. Manajemen Tenaga Kerja Indonesia Edisi Dua. Bumi Aksara: Jakarta.

Sedarmayanti. 2010. Manajemen Sumber Daya Manusia Reformasi Birokrasi Dan Manajemen Pegawai Negeri Sipil. Refika Aditama: Bandung.

Shahab, Moh Ali. 2014. The Influence of Leadership and Work Attitudes toward Job Satisfaction and
Performance of Employee. International Journal of Managerial Studies and Research (IJMSR) Volume 2, Issue 5, June 2014, PP 69-77 ISSN 2349-0330 (Print) \& ISSN 2349-0349 (Online) www.arcjournals.org. Dept. of Management, faculty of Economics, Sultan Agung University (UNISSULA) Semarang, Indonesia. Siagian, Sondang. 2002. Kiat Meningkatkan Produktivitas Kerja. Cetakan Pertama. PT. Rineka Cipta: Jakarta.

Sopiah. 2013. The Effect of Compensation toward Job Satisfaction and Job Performance of Outsourcing Employees of Syariah Banks in Malang Indonesia. International Journal of Learning \& Development ISSN 2164-4063 2013, Vol. 3, No. 2. Dept. Of Management, State University of Malang.

Wahyudi, Bambang. 2002, Manajemen Sumber Daya Manusia. Sulita: Bandung. 